\title{
Analysis and Review of The Implementation of Law Enforcement Operations Juridical Capture Corruption in The Criminal Justice System
}

\author{
Hulman Siregar $^{1}$ and Rakhmat Bowo Suharto ${ }^{2}$ \\ Abstract. Corruption has occurred in all sectors of activity in State Institutions has \\ even been categorized as an extraordinary crime. This condition has a negative \\ impact on the implementation of sustainable national development to improve \\ the welfare of the community. Because the state budget funds both central and \\ regional that can be used to build infrastructure facilities for public services such as \\ health services, education, social assistance in the form of food and clothing. \\ Become reduced due to corruption. The mindset and pattern of action in dealing \\ with corruption crime requires a leap of change so that the implementation of law \\ enforcement in combating corruption through hand-catching operations can run \\ effectively in accordance with the laws and regulations. \\ Keywords: Planned; Accurate; Accountable; Responsible.
}

\section{Introduction}

Corruption is an act that can cause harm to many people even can affect the existence and development progress and welfare of the people of a country. According to Andrea Fockema word corruption comes from the Latin corruptio or corruptus (Webster's Student Dictionary: 1960). Later appeared in English and French corruption, in the Dutch language and of Dutch Korruptie this is the word that comes down to Indonesian namely corruption. Corruption occurs in all countries around the world, the only difference is how the spread of corruption in the country, compared to other countries. ${ }^{3}$ Adolfo Beria view corruption as a worldwide phenomenon, follows the history of human existence itself. ${ }^{4}$ More Adolfo Beria stated: "There is no culture without its indigenous primordial phenomenon of corruption; there is no system (from that USA to that of Japan) the which is free from vast areas of corruption; there is no center of government (from the prairies of America to the communist collectivizations) the which has not been vitiated or distorted by corruption; there is no religion (Eastern, Judaic, Christian or Islamic) the which has not had to confront the evils connected to corruption; there is no Empire (be it Persian, Roman, British or Soviet) the which has no experienced and has not been damaged by corruption ". 5 (No original culture primordial without the phenomenon of corruption; there is no system of the United States to Japan free of the area of corruption; there is no central government (on the American prairies to the region communists) that have not been tampered with or distorted by corruption; no religion (east, Jewish, Christian or Islamic) is not against the crime of corruption; no empire (the Persians, Romans, Britain or Soviet) did not have the experience and that is not marred by corruption)".

\footnotetext{
${ }^{1}$ Student of Master of Law, Universitas Islam Sultan Agung Semarang and Associate Auditor at the Financial and Development Supervisory Agency email: hstregar@gmail.com

2 Lecturer of Faculty of Law Unissula Semarang Indonesia

${ }^{3}$ Theodorus.M.Tuanakotta 2010 Akuntasi Forensik \& Audit Investigatif Ed. 2 Jakarta: Salemba Empat p. 224.

${ }^{4}$ Adolfo Beria Global Strategi Against Corruption dalam Responding to Corruption: Social Defence Corruption and the Protection of Public Administration and The Independence of Justice up date documens on the XIII International Conggres on Social Defence Lecce Italy 1996 diedit oleh Paolo Bernasconi 2000 p.23.

${ }^{5}$ Ibid.
} 
Corruption happens everywhere, both among relatives, within a democratic system of government and communist, either on religious institutions, the phenomenon of corruption can occur. In almost every country, especially in the early years of the formation of a state of corrupt behavior of state officials and cronies rife. Mutual monitoring functions among state agencies (check and balance) is not running properly. It can be seen from the history and development of the countries of corruption perception level is currently low classified as a developed country. Corruption constantly evolving in the darkness of totalitarianism and dictatorship regimes that divide power to a handful of people who are not responsible. ${ }^{6}$

The forms of corrupt practices is growing and growing in accordance with the progress of the times both in quality and quantity. During the Dutch colonial rule corruption is still very simple, as well as in the early years of Indonesian rule as seen from the formulation of the articles of the Criminal Procedure Code. ${ }^{7} \quad$ Not excessive if the definition and mode of corruption is always evolving and changing according to the changing times. ${ }^{8}$ This condition is a concern of the member states of the United Nations Nations which was followed by Resolution No. 58/4 dated October 31, 2003 and has been ratified by the Law of the Republic of Indonesia Number 7 of 2006 on the ratification of the United Nations Against Corruption, 2003. ${ }^{9}$

The problem of corruption in Indonesia is already a complex issue and was widespread in all facets of life. ${ }^{10}$ The results of the survey and research conducted by several media and non-governmental observers of corruption shows that the level of corruption in Indonesia is still high. According to the Indonesian Corruption Watch (ICW) "Throughout the first half of 2016, law enforcement officials managed to raise the status of cases from investigation to investigation a total of 210 cases in which the state losses of Rp 890.5 billion and Rp 28 billion in bribes, SGD 1.6 million, and USD 72 thousand, ". The prosecutor's handling 133 cases, 59 cases police and KPK 18 cases. AGO most handle cases with state losses of Rp 473 billion and Rp 14 million bribe. "Police deal with 59 cases of corruption that caused state losses of Rp 252.2 billion. Meanwhile the Commission handles 18 cases which cause state losses of Rp 164 billion and Rp 28 billion in bribes value, SGD 1, ${ }^{11}$

The results of laboratory studies of Economic Sciences, University of Gadjah Mada (UGM), the value of state losses due to corruption in Indonesia during 2001-2015 reached Rp203,9 triliun.juga calculate penalty fines and confiscation of assets accumulated only Rp21,26 trillion. Total value of the loss new cases of corruption were uncovered by law enforcement officers and acts of corruption are not revealed much greater.

The facts and the fact is the case today corruption has penetrated kesegala aspects of power lines and the bureaucracy at the central and local levels, the impact and consequences are detrimental to the State Treasury. Fair and reasonable when corruption

\footnotetext{
${ }^{6}$ Darwan Prints 2002 Pemberantasan Tindak Pidana Korupsi PT Citra Aditya Bakti Bandung p.9

${ }^{7}$ Ibid p. 7

${ }^{8}$ Martiman Prodjohamidjojo 2001,Penerapan Pembuktian Terbalik dalam Delik Korupsi CV. Mandar Maju Bandung p. 7

9 Juni Sjafrien Jahja 2013 Prinsip Kehati-hatian dalam Memberantas Manajemen Koruptif pada Pemerintahan \& Korporasi,visimedia,Jakarta p.10.

10 Puslitbang Kejaksaan Agung R.I Studi tentang Peranan Alat Bukti Keterangan Ahli Dalam Penanganan Perkara Tindak Pidana Korupsi 2008

${ }^{11}$ https://news.detik.com/berita/3285348/icw-500-orang-jadi-tersangka-kasus-korupsi-sepanjang-januarijuni-2016.
} 
in Indonesia can be categorized at level unusual conditions, so as to cope with the extraordinary events we need a strategy. Corruption eradication strategy can be achieved through efforts:

- Preventive strategies; Preventive measures directed to minimize the causes of corruption;

- Detective strategy; The detective strategy directed to the case of an act of corruption, such actions will be known quickly and accurately, so that it can quickly take action;

- Repressive strategies; Repressive strategies directed to any corruption that are identified can be checked and investigated quickly and accurately so that known to sit persolannya to then be given the appropriate sanctions by following legal procedures. ${ }^{12}$ One law enforcement efforts in combating corruption more intensively carried out by law enforcement officials are caught operating a hand better known as OTT.

Based on the background described above, the authors formulate some issues that I'll focus on analyzing the yuridid, namely:1)How process of corruption through operation hand catch the Indonesian criminal law system? 2)What is the legal basis for the implementation of anti-corruption through operation hand catch the Indonesian criminal law system?

\section{Results And Discussion}

The problem of corruption in Indonesia since the days of the old order until the time of reformation had been developed in accordance with the development of society and information technology, followed by changes and adjustments pemeberantasan law on corruption in Indonesia in accordance with the development of the incident mode acts of corruption. Efforts and law enforcement activities carried out by way of a systems approach, where the system is comprised of sub-sub-system of the substance of the law by law enforcement officials in accordance legal structure, which is expected to create and increase awareness of the laws that are part of the legal culture. All that is expected to achieve the purpose of the law or legal ideals. Gustaf legal philosophy Radbruch (1940) which states that the law is a cultural factor that realize the value of justice, ${ }^{13}$ : Legal certainty; Justice; usefulness.

Combating corruption is continuously carried out by law enforcement officials, one of the forms and porses enforcement of anti-corruption efforts is the implementation of the fishing operation of the hand or known by OTT. OTT melalaui law enforcement has shown satisfactory results in which many state officials were arrested for corruption. News that still holds true today in the electronic and print media is the judge who was arrested KPK arrest of Cooperatives melalaui hand.Unscrupulous judge in the District Court (PN) Medan reportedly netted Capture Operation Hand (OTT) team of the Corruption Eradication Commission (KPK) on Tuesday. Febri Diansyah KPK spokesman, ${ }^{14}$ confirmed that the morning until this afternoon, the Commission has secured at least 8 people for further

\footnotetext{
12 Badan Pengawasan Keuangan dan Pembangunan Strategi Pemberantasan Korupsi Nasional Pusat Pendidikan dan Latihan Pengawasan BPKP Jakarta 1999 p.41.

${ }^{13}$ R.H.Soejadi,2017 Refleksi Mengenai Hukum dan Keadilan Aktualisasinya Di Indonesia Yogyakarta : Aswaja Pressindo p.87.

${ }^{14}$ http://pekanbaru.tribunnews.com/2018/08/28/hakim-pengadilan-negeri-medan-dikabarkan-terjaring-ottkpk
} 
inspection process. Of 8 (eight) were secured, there are 3 (three) judges.

The Supreme Court as an institution that houses the high state of the judiciary under the spotlight of society that the arrests illustrate how tangled and corrupt law enforcement in our justice system. Of 8 (eight) who secured the capture operation KPK. Four (4) suspects were set, including Merry. Three others are Helpandi as clerk of replacement PN Medan, Tamin Sukardi from the private sector and Hadi Setiawan called confidante Tamin. ${ }^{15}$ Determination of four (4) persons suspected of eight (8) people were netted in the operation carried KPK hand caught in the Medan District Court raises many questions.

According Luhut Pangaribuan in posts in Social Media dated August 29, 2018 "Judge when arrested for Capture Operation Hand (OTT) is very embarrassing and bad. Punishment should be more severe. But mistakes suspect and arrested more shameful and worse by law. Therefore, if the judge Medan, KPN and his deputy were released because there was no indication of criminal accepting bribes or promises are entitled to rehabilitation and the Commission should apologize. His name is already damaged because pulikasi as judges should be restored immediately by the Commission which could catch it. At least need a full explanation to the public. In law, arrest a person does not bias is based on prejudice. Do not let it become public confidence.

\subsection{The Implementation Process of the Corruption Eradication through Operation Hand Catch the Indonesian Criminal Justice System.}

The process of implementation of the eradication of corruption through hand fishing operations in particular performed by the KPK is an implementation plan has been developed. The plan has been mapped through the identification of potential risk of corruption, which is done through the study, coordination, supervision and prevention, known as korsupgah. The plan was developed with information obtained from the community, reviewed, investigated, monitored and monitored intensively. Once the alleged criminal act happens, the prosecution is based on strong preliminary evidence.

Perpetrators of alleged corruption that netted through hand fishing operation arrested under strong preliminary evidence in accordance with Article 17 of the Criminal Procedure Code. The arrest was made for no longer than one day in accordance with the Criminal Procedure Code Article 19 paragraph (1), which in practice during the next 24 hours to be determined whether the status remains detained as suspects or released. Referring to the case of the operation to catch the hand that happened on the Medan District Court which encompass eight (8) persons including four (4) judges, which are processed so suspect and detained four (4) members and four (4) people released them three (3) judges. The question arises whether the arrest of eight (8) persons who netted in the implementation of the arrest operation carried out by the hands of a strong preliminary evidence?

Currently the investigation process is still running and the judge who released KPK investigators examined as a witness. Handling of law enforcement on suspicion of corruption, which implements the operation results capture interesting hands to be studied in depth. If at the end of the judicial process has been legally binding and the three judges who had been arrested and released are not shown to be associated with corruption will lead to legal proceedings and set a precedent for the implementation of the judicial power in check, hear and decide the case in accordance with Act No. 48 Of

\footnotetext{
${ }^{15}$ https://news.detik.com/berita/4187708/ott-di-medan-kpk-tetapkan-hakim-dan-panitera-jadi-tersangka
} 
2009 on Judicial Power.

Implementation of law enforcement, especially in the hands perapan fishing operations should be done carefully and measured in accordance with the law existing event so the implementation of the law enforcement reach tujuannnya namely, justice oriented legal certainty, fairness, and benefits. A legal term that can embrace the ideals of criminal justice, according to Muladi that due process of law in the Indonesian language can be translated into a fair legal process or feasible. ${ }^{16}$

\subsection{Implementation of Anti-Corruption Legal basis through Operation Hand Catch the Indonesian Criminal Law System}

It is undeniable that the reality of the development of legal events, especially events of criminal law is much faster and dynamic compared with undangang laws are there, so many events of law and law enforcement are not regulated and are not clearly defined either law or legal material formilnya. In practice, law enforcement is required reasoning and interpretation supported by the argument his legal logic in accordance with the criminal law pinsip. This is supported by the occurrence of corruption are categorized as a criminal offense by extraordinary events (extraordinary crime) so that handling is also necessary legal steps are progressive and innovative.

There are various opinions, comments and arguments from experts and legal observers were raised over the implementation of law enforcement with hand fishing operations, grouped into two groups to agree and disagree. One of the opinions that do not agree with the rule of law through the operation of the hand catch isLeica Marzuki in a pretrial hearing against KPK in Jakarta District Court (PN) South Jakarta, Thursday (27/10). In a statement, calling Laica Capture Operation Hand (OTT) is not recognized in the procedural law, the Daily Policy, dated October 28, 2016. The reality is that a lot of corruption that was revealed resulting from the implementation of the fishing operation of the hand.Hand fishing operations implicitly not formulated in the Criminal Code but it does not mean the enforcement through hand fishing operations in particular law enforcement law enforcement corruption is not legally valid. George P.Fletcher suggests there are twelve basic concepts of criminal law, among others substasi concept versus procedure. A person who commits a crime, in substance has violated the law. ${ }^{17}$ If the principle of criminal law is associated with the formulation of a crime is caught in the Criminal Code Article 1 point 19 , the formulation can be used as a base of operations to catch the hand by taking into account the requirements as stipulated in the Criminal Code Article 17, namely, the precepts of the arrests were made against a person suspected hard with a criminal offense based on sufficient preliminary evidence. ${ }^{18}$

Fishing operations in the hands of law enforcement criminal offense krupsi substance criminal acts within the scope of the scope of the formulation was caught stipulated in Article 1 point 19 of the Criminal Procedure Code, namely ${ }^{19}$ :

Caught in the act was the arrest of a person at the time of committing a crime or immediately after some time the criminal act was done, or shortly afterwards called for

\footnotetext{
${ }^{16}$ Muladi 1997 Hak Asasi Manusia Politik dan Sistem Peradilan Pidana Badan Penerbit UNDIP Semarang p.62.

${ }^{17}$ Eddy.O.S.Hiariej,2016,Prinsip-Prinsip Hukum Pidana Yogyakarta: Cahaya Atma Pustaka p.53.

${ }^{18}$ Indonesia the Law on Criminal Proceedings (Criminal Procedure Code) Act No. 8 LN No. 76 of 1981 Supplement No. 3209 ch. 17.

19 Ibid. Ar..1 no.19.
} 
the general public as a person who did it, or when moments later her found objects allegedly used to commit the crime which shows that he is the culprit or participating in or aiding and abetting the crime.

If observed carefully formulated definition is caught in the Criminal Code and implementing such fishing operations undertaken in the hands of law enforcement in order to eradicate corruption is substantially the arrest of a person, participating in, or aiding and abetting a criminal offense. Legal action against the act was caught as defined above or in the hand fishing operations (OTT) if certain terms are met and that their strong preliminary evidence as to which are set out in Article 17 of the Criminal Procedure Code.

\section{Closing}

Based on the whole description in the discussion above may be derived some fruit idea as follows:

\subsection{Conclution}

- The process of implementation of law enforcement through hands fishing operations conducted through an accurate planning and integrated gathered from a variety of data and information, dimnitr and analyzed on an ongoing basis to gather strong preliminary evidence as the basis for the implementation of follow-up operations to catch the hand.

- The formulation was caught as stipulated in Article 1 point 19 of the Criminal Code can be used as a reference in the implementation of law enforcement with fishing operations in hand with meeting the requirements specified in Article 17 of the Criminal Procedure Code.

\subsection{Suggestion}

Legal action will be carried out law enforcement officers in law enforcement corruption as a follow-up operations to catch the hand must be made accountable, caution and should be based on strong preliminary evidence.

\section{Bibliography}

[1] Ali Mahrus 2011 Hukum Pidana Korupsi di Indonesia Yogyakarta: UII Press.

[2] Arief Barda Nawawi 2010 Masalah Penegakan Hukum dan Kebijakan Hukum Pidana dalam Penanggulangan Kejahatan Jakarta: Predanamedia.

[3] B.Carada Alfredo 2009 Korupsi Sumber Daya Alam dan Isu Lingkungan Korupsi Mengorupsi Indonesia Jakarta: Gramedia Pustaka.

[4] Harahap M.Yahya 2006 Pembahasan Permasalahan dan Penerapan KUHAP Jakarta: Sinar Grafika.

[5] Juni Sjafrien Jahja 2013 Prinsip Kehati-hatian dalam Memberantas Manajemen Koruptif pada Pemerintahan \& Korporasi.

[6] Mardjono Reksodiputro 1993 Sistem Peradilan Pidana Indonesia (Melihat Kepada Kejahatan Dan Penegakan Hukum Dalam Batas-Batas Toleransi) Faculty of Law Indonesia Unversity.

[7] Muladi 1997 Hak Asasi Manusia Politik dan Sistem Peradilan Pidana Badan Penerbit UNDIP Semarang.

[8] Marwan Efendi 2010 Pemberantasan Korupsi dan Good Governance PT Timpani Publishing. 